THE imbalance of T-helper (Th) lymphocyte cytokine production may play an important role in immunopathogenesis of persistent hepatitis $\mathrm{C}$ virus (HCV) infection. To know whether an imbalance between Th 1 and Th 2 cytokines is present in chronic HCV infection, serum levels of Th 1 cytokines, in terferon gam ma (IFN- $\gamma$ ) and in terleukin (IL) - 2 , and Th 2 cytokines, IL-4 and IL-10, were measured using enzymelinked immunosorbent assay in this study. Eighteen individuals with chronic HCV infection, 11 healthy subjects as normal controls and 10 chronic HBV infected patients as disease controls were observed. The results showed that the levels of Th 2 cytokines (IL-4 and IL-10) were significantly increased in chronic HCV infected patien ts compared with normal controls (IL-4: $30.49 \pm 17.55$ vs. $14.94 \pm 13.73, \mathrm{pg} / \mathrm{ml}$, $P<0.025$; IL-10: $50.30 \pm 19.59$ vs. $17.87 \pm 9.49, \mathrm{pg} / \mathrm{ml}$, $P<0.001)$. Similarly, the levels of Th 1 cytokine, IL-2, was also elevated in individuals with chronic HCV infection when compared with normal controls (IL-2: $118.53 \pm 95.23$ vs. $61.57 \pm 28.70, \mathrm{pg} / \mathrm{ml}, P<0.05)$. However, Th 1 cytokine IFN- $\gamma$ level was not sig$n$ ifican tly changed during $\mathrm{HCV}$ in fection (IFN- $\gamma: 28.09$ \pm 15.65 vs. $24.10 \pm 15.61, \mathrm{pg} / \mathrm{ml}, P>0.05)$. Fur thermore, the elevated levels of Th 2 cytokines are greater than Th 1 cytokines in HCV infection. Thus, the study indicates that an enhanced Th 2 responses are present during chronic HCV infection, which may partly be responsible for the persistence of $\mathrm{HCV}$ in fection.

Key words: Hepatitis C virus, Thelper lymphocytes, Cytokines

\section{Circulating Th1 and Th2 cytokines in patients with hepatitis $C$ virus infection}

\author{
X. G. Fan, ${ }^{1, C A}$ W. E. Liu, ${ }^{1}$ C. Z. Li, ${ }^{1}$ Z. C. Wang, ${ }^{2}$ \\ L. X. Luo, ${ }^{1}$ D. M. Tan, ${ }^{1}$ G. L. Hu ${ }^{1}$ and Z. Zhang ${ }^{1}$
}

Departments of ${ }^{1}$ Infectious Diseases and ${ }^{2}$ Blood Transfusion, Xiangya Hospital, Hunan Medical University, Changsha, Hunan, People's Republic of China

${ }^{\mathrm{CA}}$ Corresponding Author
Fax: $(+86) 7314471339$

\section{Introduction}

Hepatitis C virus (HCV) infection has been confirmed to be the major aetiologic agent for posttransfusion hepatitis all over the world. One of the characteristic features is at least half of the infection to become chronic. ${ }^{1-3}$ The high mutational rate of the viral genome is considered to be responsible for persistent $\mathrm{HCV}$ infection. ${ }^{3}$ The inability of the host immune function to eliminate an organism is also an important cause for persistentive form of infection. ${ }^{4}$ However, little has been learned about the host cellular immune response to $\mathrm{HCV}$. The role of the immunoregulatory cytokines in chronic $\mathrm{HCV}$ infection is recently being stressed., ${ }^{5,6}$ this study, to better know the profiles of cytokines production in individuals with chronic HCV infection, we measured serum levels of Thelper lymphocytes (Th) 1 cytokines interferon gamma (IFN- $\gamma$ ), interleukin (IL)-2, and Th2 cytokines IL-4, IL-10 in such patients.

\section{Subjects and Methods}

\section{Subjects}

Eighteen patients with chronic $\mathrm{HCV}$ infection were included in this study. The diagnosis of chronic HCV infection was based on the seropositivity of $\mathrm{HCV}$ specific antibody and HCV-RNA for at least 6 months of $\geq 2$ times detection. There was no serologic evidence of co-infection with other hepatotropic viruses. Other possible causes of hepatocellular injury, such as alcohol, drugs and autoimmune diseases were also excluded. No immunoregulatory agents were administered in recent 3 months before enrolment. The characteristics of 18 chronic $\mathrm{HCV}$ infected individuals were summarized in Table 1.

As normal controls, 11 healthy subjects who were negative for both serum anti-HCV and hepatitis $B$ virus (HBV) markers were selected without a clinical history of hepatitis and without symptoms or signs of liver diseases (seven males and four females; mean age 32 years, range 20-47 years). Also, 10 chronic 
Table 1. Details of individuals with chronic HCV infection

\begin{tabular}{|c|c|c|c|c|c|c|}
\hline Patient & $\begin{array}{l}\text { Sex } \\
\text { (F/M) }\end{array}$ & $\begin{array}{c}\text { Age } \\
\text { (years) }\end{array}$ & $\begin{array}{l}\text { Blood transfusion } \\
\text { history (time) }\end{array}$ & Anti-HCV & HCV-RNA & $A L T(U / L) *$ \\
\hline 1 & $\mathrm{~F}$ & 30 & yes (1995) & + & + & 150 \\
\hline 2 & $\mathrm{~F}$ & 23 & no & + & + & $<40$ \\
\hline 3 & $M$ & 68 & yes (1995) & + & + & 138 \\
\hline 4 & M & 40 & yes (1993) & + & + & 184 \\
\hline 5 & $\mathrm{M}$ & 42 & yes (1989) & + & + & 66 \\
\hline 6 & $\mathrm{~F}$ & 27 & yes (1990) & + & + & 180 \\
\hline 7 & $M$ & 58 & yes (1995) & + & + & 158 \\
\hline 8 & $M$ & 49 & yes (1992) & + & + & 252.2 \\
\hline 9 & $\mathrm{~F}$ & 51 & yes (1991) & + & + & $<40$ \\
\hline 10 & $\mathrm{~F}$ & 61 & yes (1989) & + & + & $<40$ \\
\hline 11 & $M$ & 26 & yes (1995) & + & + & 60.5 \\
\hline 12 & $M$ & 44 & yes (1992) & + & + & 760 \\
\hline 13 & M & 45 & yes (1993) & + & + & 48.5 \\
\hline 14 & $\mathrm{~F}$ & 28 & yes (1994) & + & + & 74.3 \\
\hline 15 & $M$ & 38 & yes (1994) & + & + & 742 \\
\hline 16 & M & 43 & yes (1994) & + & + & 48 \\
\hline 17 & $\mathrm{~F}$ & 54 & yes (1990) & + & - & 71.7 \\
\hline 18 & $\mathrm{~F}$ & 66 & yes (1990) & + & + & 129.8 \\
\hline
\end{tabular}

${ }^{*}$ ALT: alanine transaminase, normal value $\leq 40 \mathrm{U} / \mathrm{l}$.

hepatitis $B$ patients (seven males and three females, mean age 38 years, range 23-56 years) with no se rologic evidence of $\mathrm{HCV}$ infection were recruited as disease controls, who had seropositivity of $\mathrm{HBV}$ markers and abnormal liver tests for more than 6 months.

\section{Methods}

Serologic detections of HBV markers, anti-HCV (a second-generation test) were carried out using commercially available enzyme-linked immunosorbent assay (ELISA) kits (Sino-American Biotechnology Company, Louyan, China). The procedures were performed according to the manufacturer's instruction. Serum HCV-RNA was determined by reverse transcription polyme rase chain reaction (RT-PCR). Briefly, RNA was extracted from the samples by single step method as described previously. ${ }^{7}$ The amplification was done after an initial denaturation step $\left(94^{\circ} \mathrm{C}\right.$, $5 \mathrm{~min})$ by 32 cycles $\left(94^{\circ} \mathrm{C}, 30 \mathrm{~s} ; 58^{\circ} \mathrm{C}, 30 \mathrm{~s} ; 72^{\circ} \mathrm{C}\right.$, $1 \mathrm{~min}$ ) and $5 \mathrm{~min}$ at $72^{\circ} \mathrm{C}$ in a thermocycler (PerkinElmer Cetus, Changsha Branch, Changsha, China). The amplified cDNA fragments were analysed on a $1.5 \%$ agarose gel. The bands were visualized by ethidium bromide staining.
Quantification of serum cytokines was measured by ELISA using commercially available kits (Genzyme, Shenzheng Branch, Shenzheng, China). The sera were stored at $-30^{\circ} \mathrm{C}$ until assay (in 3 months) and each sample was examined in duplicate. The assays were performed following the manufacturer's instruction.

\section{Statistics}

Data were analysed by non-parametric test and expressed as mean \pm standard division.

\section{Results}

The serum levels of IFN- $\gamma$, IL-2, IL- 4 and IL-10 were measured in patients with HCV or HBV infection and normal controls. As shown in Table 2, Th2 cytokines (IL-4 and IL-10) levels were significantly increased in chronic HCV infected patients compared with normal controls $(P<0.025, P<0.001)$. Similarly, the levels of the Th 1 cytokine, IL-2, was also elevated in individuals with chronic $\mathrm{HCV}$ infection when compared with normal controls $(P<0.05)$. However, Th1 cytokine IFN- $\gamma$ level was not significantly changed during $\mathrm{HCV}$ infection $(P>0.05)$.

Table 2. The comparison of serum cytokines in three studied groups

\begin{tabular}{lcccc}
\hline & IFN- $\gamma(\mathrm{pg} / \mathrm{ml})$ & IL-2 $(\mathrm{pg} / \mathrm{ml})$ & IL-4 $(\mathrm{pg} / \mathrm{ml})$ & $\mathrm{IL}-10(\mathrm{pg} / \mathrm{ml})$ \\
\hline Control & $24.10 \pm 15.61$ & $61.57 \pm 28.70$ & $14.94 \pm 13.73$ & $17.87 \pm 9.49$ \\
HBV infection & $32.48 \pm 19.99$ & $56.75 \pm 20.04$ & $21.44 \pm 11.23$ & $31.16 \pm 17.15^{* *}$ \\
HCV infection & $28.09 \pm 15.65$ & $118.53 \pm 95.23^{*}$ & $30.49 \pm 17.55^{* *}$ & $50.30 \pm 19.59^{* *}$ \\
\hline
\end{tabular}

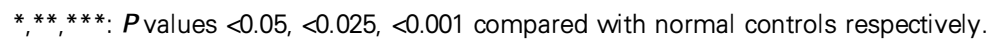


Table 3. The relation of cytokines and ALT in HCV infection

\begin{tabular}{lllll}
\hline ALT (U/L) & IFN- $\gamma(\mathrm{pg} / \mathrm{ml})$ & $\mathrm{IL}-2(\mathrm{pg} / \mathrm{ml})$ & $\mathrm{IL}-4(\mathrm{pg} / \mathrm{ml})$ & $\mathrm{IL}-10(\mathrm{pg} / \mathrm{ml})$ \\
\hline >100 & $25.94 \pm 14.77$ & $132.36 \pm 107.08$ & $36.71 \pm 21.74$ & $51.97 \pm 24.46$ \\
$\leq 100$ & $30.24 \pm 16.20$ & $104.71 \pm 79.31$ & $24.28 \pm 8.11$ & $48.63 \pm 11.01$ \\
\hline
\end{tabular}

ALT: alanine transaminase, no significance difference in each group.

In chronic $\mathrm{HBV}$ infected patients, serum levels of IFN- $\gamma$, IL- 4 and IL-10 we re higher than those in normal controls, though only IL-10 level reached a statistical difference (Table 2). Furthermore, the elevated level of serum IL-10 was smaller in $\mathrm{HBV}$ infected patients compared with that in $\mathrm{HCV}$ infected patients.

The serum levels of IFN- $\gamma$, IL- 2 , IL -4 and IL-10 have not been found to be related to serum activity of alanine transaminase (ALT) in $\mathrm{HCV}$ infected individuals (Table 3).

\section{Discussion}

It has been demonstrated that Th lymphocytes may be subdivided into Th1 and Th2 cells based on the distinct patterns of cytokine production. ${ }^{8}$ Th 1 cells produce IFN- $\gamma$, IL-2 and lymphotox in which promote cell-mediated effector responses; whereas Th2 cells produce IL-4, IL-5, IL-6 and IL-10 cytokines which influence B-cell development and can augment humoral responses. Cytokines released by one type of Th lymphocyte population can down-regulate the functions of another Th population. Th 1 responses are associated with immunity or resistance to infection, while Th2 responses are associated with the progression or persistence of infection. ${ }^{9,10}$ A shift of Th 1 to Th2 2 responses has been implicated in the pathogenesis of some infectious diseases, such as human immunodeficiency virus infection, mycobacterial and protozoal diseases. ${ }^{4,10}$

Inflammatory cytokines play an important role in pathogenesis of hepatitis $\mathrm{B} .{ }^{11}$ However, the reports on the manner of cytokines in chronic HCV infection are rare. The current study showed that the increased production of Th1 (IFN- $\gamma$ and IL-2) and Th 2 (IL 4 and IL-10) cytokines are present in HCV infection, suggesting Th cells are activated in vivo due to $\mathrm{HCV}$ infection. This results is in agreement with another observation reported by Cacciarelli. ${ }^{6}$ It is also noted that the elevated levels of Th2 cytokines are greater than Th1 cytokines in HCV infection. In view of negative regulation of Th2 cytokines for immune functions, ${ }^{4}$ we consider that enhanced Th2 reaction is at least partly responsible for immunopathogenesis of chronic HCV infection. We also propose that enhanced Th2 responses in HCV infection may allow the human host to suppress the inflammatory/ immune responses, ${ }^{12,13}$ resulting in reducing the hepatic tissue injury through down-regulation of the inflammatory/immune reaction and leading to inability to eliminate the virus. This is one possible explanation why HCV infection tends to be a chronic condition. To further elucidate the role of these cytokines in immunopathogenesis of chronic $\mathrm{HCV}$ infection, the levels of mRNA expression for intrahepatic Th cytokines are currently performing.

Similarly, an increased production of IL-10 was observed for chronic HBV infection in the study. Based on the results in this study, enhanced Th2 responses, however, are obviously weaker in $\mathrm{HBV}$ infection than in HCV infection. It is possibly one of the causes that the chronic feature is more common in $\mathrm{HCV}$ infection than in HBV infection.

\section{References}

1. Kiyosawa K, Sodeyama T, Tanaka E, Gibo Y, Yoshizaw a K, Nakano Y, et al. Interrelationship of blood transfusion, non-A, non-B hepatitis and hepatocellular carcinoma: analysis by detection of antibody to hepatitis C virus. Hepa tology 1990; 12: 671-675.

2. Weiner AJ, Geysen HM, Christopherson C, Hall JE, Mason TJ, Saracco G, et al. Evidence for immune selection of hepatitis $\mathrm{C}$ virus (HCV) putative envelope glycoprotein variants: potential role in chronic HCV infections. Proc Natl Acad Sci USA 1992; 89: 3468-3472.

3. Iw ata K, Wakita T, Okumura A, Yoshioka K, Takayanago M, Wands JR, et al. Interferon gamma production by peripheral blood lymphocytes to hepatitis $C$ virus core protein in chronic hepatitis C infection. Hepa to logy 1995; 22: 1057-1064.

4. Modlin RL, Nutman TB. Type 2 cytokines and negative immune regulation in human infections. Curr Opin Immunol 1993; 5: $511-514$.

5. Bertoletti A, D'Elios MM, Boli C, Carli MD, Zignego AL, Durazzo M, et al. Different cytokine profiles of intrahepatic T cells in chronic hepatitis B and hepatitis C virus infections. Gastroenterology 1997; 112: 193-199.

6. Cacciarelli TV, Martinez OM, Gish RG, Villanueva JC, Krams SM. Immunoregulatory cytokines in chronic hepatitis $C$ virus infection: preand posttreatment with interferon alfa. Hepatology 1996; 24: 6-9.

7. Chomczynski P, Sacchi N. Single step method of RNA isolation by acid guanidinium thiocyanate-phenol-chloroform extraction. Ann Biochem 1987; 162: 156-158.

8. Fan XG, Yakoob J, Fan XJ, Keeling PWN. Effect of IL -4 on peripheral blood lymphocyte proliferation: implication in immunopathogenesis of $H$. pylori infection. Im munol Lett 1995; 48: 45-48.

9. Fan XG, Yakkob J, Fan XJ, Keeling PWN. Enhanced Th2 responses: immune mechanism of $H$. pylori infection. Ir J Med Sci 1996; 165: 37-39.

10. Clerici M, Shearer GM. TH1-TH2 switch is a critical step in the etiology of HIV infection. Im mu nol Today 1993; 14: 107-110.

11. Fan XG, Zhang Z. Increased tumour necrosis factor $\alpha$ production by neutrophils in patients with hepatitis B. J Clin Pathol 1994; 47: 616-618.

12. Hoffmann RM, Diepolder HM, Zachoval R, Zw iebel FM, Jung MC, Scholz $\mathrm{S}$, et al. Mapping of immunodominant CD4+ T lymphocyte epitopes of hepatitis $C$ virus antigens and their relevance during the course of chronic infection. Hepatology 1995; 21: 632-638.

13. Tsai SL, Liaw YF, Yeh CT, Chu CM, Kuo GC. Cellular immune responses in patients with dual infection of hepatitis B and C viruses: dominant role of hepatitis C virus. Hepa tology 1995; 21: 908-912.

\section{Received 16 March 1998; \\ accepted 8 May 1998}




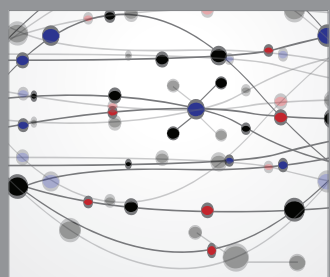

The Scientific World Journal
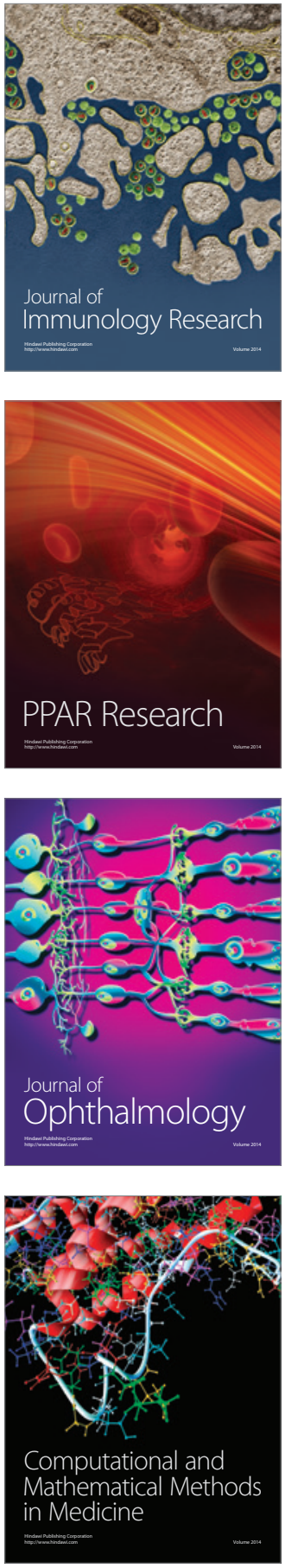

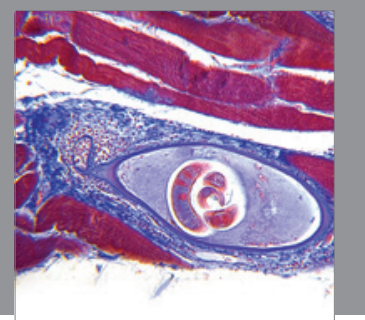

Gastroenterology

Research and Practice
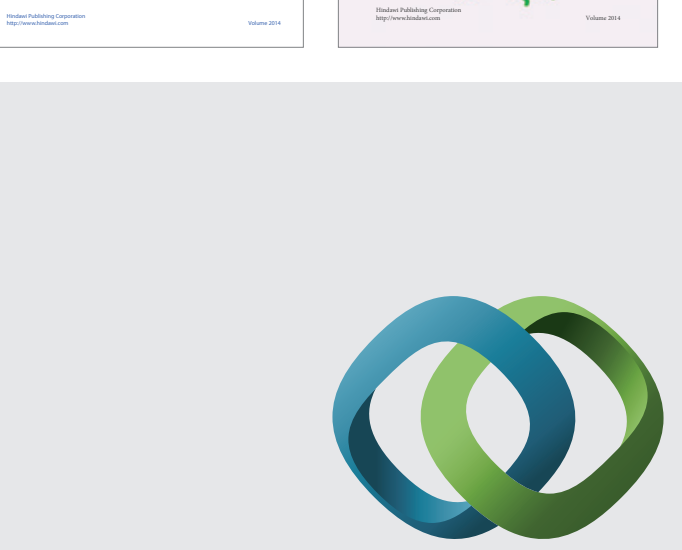

\section{Hindawi}

Submit your manuscripts at

http://www.hindawi.com
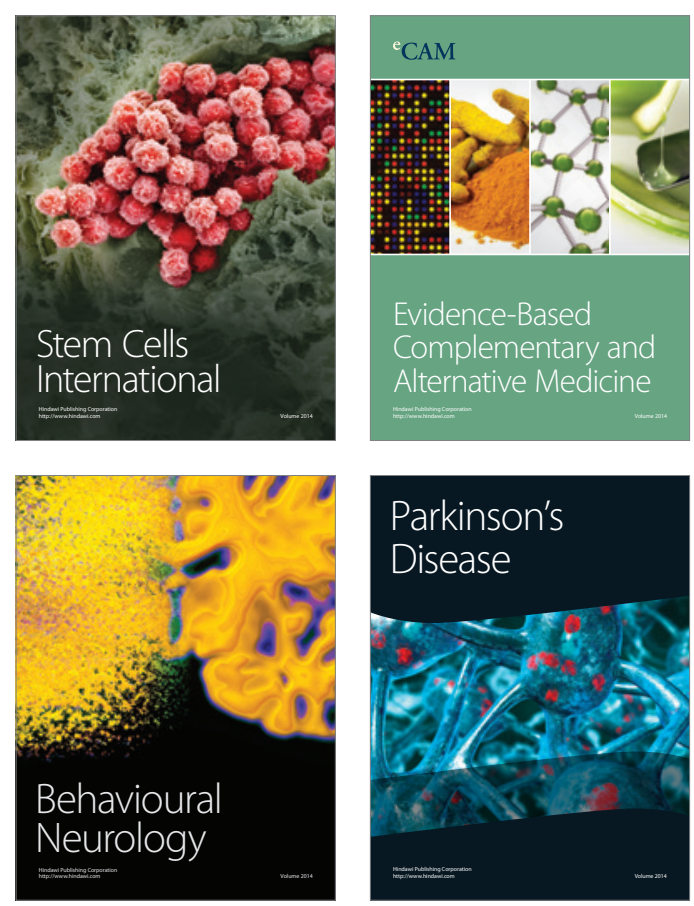

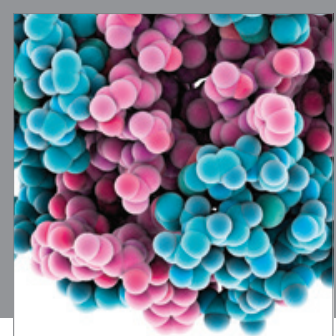

Journal of
Diabetes Research

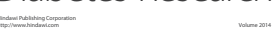

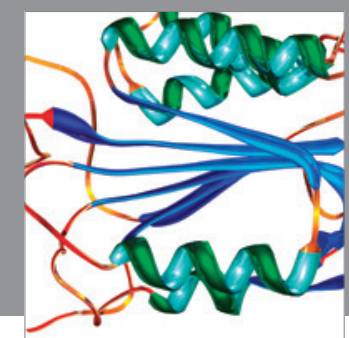

Disease Markers
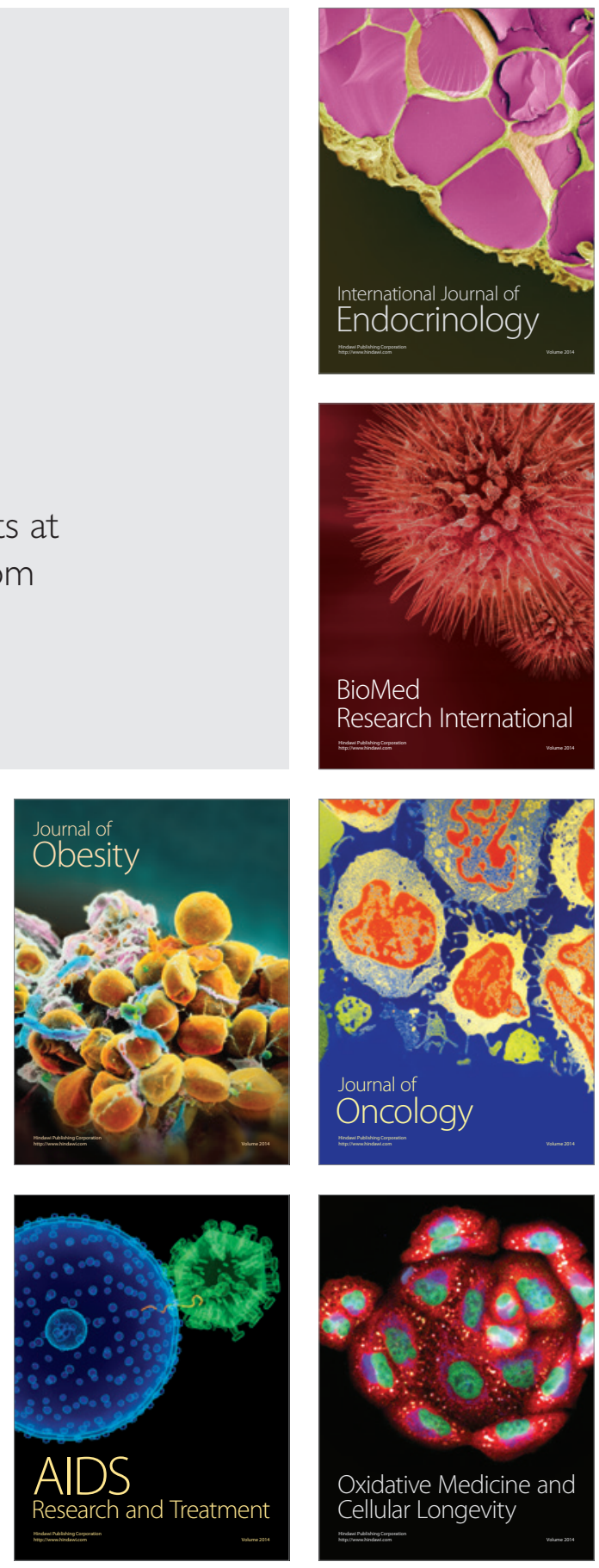